International Research Journal of Management, IT \& Social Sciences (IRJMIS)

Journal Homepage: http://ijcu.us/online/journal/index.php/irjmis

Vol. 3 Issue 7, July 2016, pp. 23 39

ISSN: 2395-7492 Impact Factor: 3.552

DOI: 10.6084/m9.figshare.3437297 | ORCID: 0000-0003-3865-8388 | Thomson Reuters ID: C-6767-2016 |

\title{
Business Plan for Ade Farm Food Production Company NIG LTD
}

\author{
Adejare Yusuff Aremu * \\ Adediran Daud Shola **
}

Article history:

Received April 5 th $^{\text {, }} 2016$

Revised May $15^{\text {th }}, 2016$

Approved June $19^{\text {th }}, 2016$

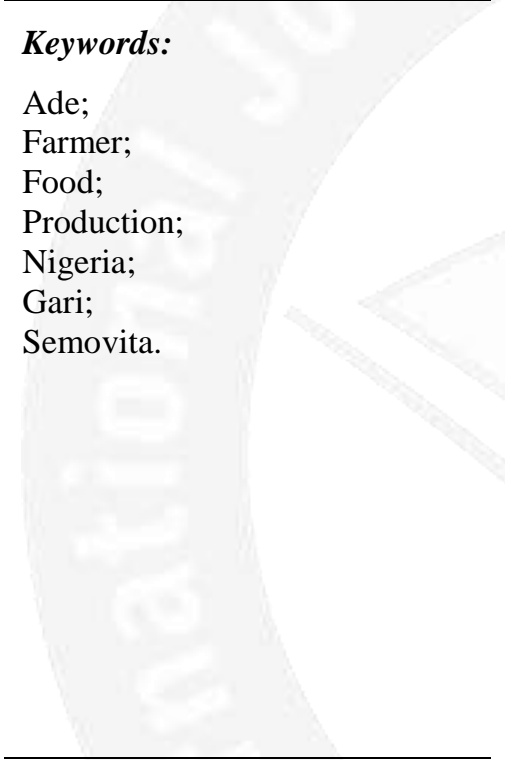

Author correspondence:

\begin{abstract}
Ade Farmers Food Production is a family farms business, it focus to be produce more food in quantity and to be packaging in a different $\mathrm{kg}$, also to be added to value of Nigeria economies and to be contribute many benefit for communities. In addition, we have plan to extend to many countries in Asia, like Malaysia, china, Dubai. Farmers Food production is the one of successful food farms. The idea behind the business is to provide healthy and delicious semovita and mails to the public. In addition to semovita and mails the company plans to produce and market manure compost garden amendment products. Farmers Food productions being formed from the family successful food farms, The latter has long-researched horticultural and agronomic techniques, as well as compost and land blending technology now being promoted by the farmer association of Oyo state agencies. The company is a combination of cutting edge, highest quality, and efficient food technology and production. It is committed to the improvement of food production in the nation and nutritional quality. It is being founded to build upon an extensive array of biological and horticultural education, experience, and the research of its founders. This is further coupled with the experience of Mr. Akeeb, the current manager of Farmers Food Farm, and consultation with the present owner of Food Farm, Mr. Ademola A.A. Farmers Food production is a Kisi-based company, located in Oyo state Nigeria, whose mission is to provide high quality, nutritional, and flavorful semovita and gari for consumption in both near and remote regions of the Nigeria. Additionally the company will provide high quality planting materials for use nationwide.
\end{abstract}

Copyright (0) 2016 International Journal of College and University. All rights reserved.

Article cited by | DOI |Orcid | OAI DOAJ | Thomson Reuters | Scopus |

First Author,

Othman. Yeop Abdullah Graduate School of Business, University Utara Malaysia

Email: akogunadejare@yahoo.com

\section{Introduction}

Nigeria is the largest population country in Africa, with population of 180 million and still a commercial Country. Nigeria is growing very well in term of agriculture and others business, but the food still not circulate the country and still cost in many places in the part of the country. So I am writing this business Plan for this farm food production company to be producing more food for the benefit of people by low cost price and quantity, so that it will more easers for customer to buy and to added more to economies of the nation. This farm is producing these types of food (SEMOVITA, CASSAVA FLOWER, and MAIZE FLOWER AND YAM FLOWER) in Nigeria name is (Semovita, Gari or Eba and Amala) this food company is going to expand too many country later after 2 to 3years, we are target country like:-Malaysia, china and Dubai. According to the Product Manager of Semovita and Ball Foods at FlowerMills Ltd, Miss

*Othman Yeop Abdullah Graduate School of Business, University Utara Malaysia

${ }^{* *}$ Ghazali Shafie Graduate School of Government, University Utara Malaysia 
ChinenyeNjideo for, Semovita is a brand that has been in existence for 50 years and holds 70 percent share of the semolina market in Nigeria, hence the need for an advertising campaign that is worthy of the position the brand commands in the market. Stating the benefits of the product, Njideo for stated that Semovita commands the market share it does because it contain fibre, which makes for easy digestion when consumed, is high in protein, low in fat and can be consumed anytime of the day because it is easily digestible in the stomach.

In his remarks, Milling Director at Flower Mills, Mr. Solomon Obichukwu, who also represented the Food production Managing Director of the Company, "Flower Mills uses the latest technology to extract the rich fibre embedded in the fibrous layers of the wheat." He further states that since there are about 20 types of wheat, the company had to make sure that the highest quality wheat was used to make Semovita, using a computerized milling system which prevents essential amino acids from being lost when being processed. The name "Semovita" he said is derived from the first four letters of the words "Semolina" and "Vitamin".

How to process yam into yam Flower used as pounded yam. Pound yam is eaten in every state in the country, Nigerian aboard also enjoy this meal, but come to hink of it, the energy that goes into preparing pounding yams is not for weakling, in some places the ladies do the cooking while the men do the pounding, while in some places the women do the cooking and the Pounding ( no be small work )So if you go into Yam Flower processing and packing you are actually selling convenient and time to your consumers, you saving time to do the pounding and the energy. So package yam Flower that will be ready in 5-10minutes. The basic raw material needed for this venture is yam and we have abundant in Nigeria, the good news is that Nigeria is the largest producers of yam in the World. A lot of states plant yam, some in Commercial quantities while other in small quantities. River, Oyo state, all have in commercial quantities, however it is important to note that is not all type of yams specie that is used for yam Flower. The technology behind yam Flower is simple. Cassava Flower is an acceptable among Africans, Asians and some other parts of the world as raw materials in bakeries. Just like Semovita, Semolina etc., it is also eaten as food by many. Pharmaceutical companies also use it as raw material. Its processing increases its shelf life, adds value to the cassava tubers (from where it is processed) before being exported to enhance its economic value, reduces waste and cuts down the cost of transporting the product to longer distances compared with the heavy wet cassava tubers that are unprocessed.

\section{Research Method \\ 2.1 Population}

As the unit analysis of the study is at individual level, the population comprises of customer's from various cities and towns in Oyo state. This customer's were employed into the various departments of the oyo state. As the unit analysis of the study is at individual level, the population comprises total of (33 Local).There will be small sampling procedures to establish for the study, which will consist of (Individual) customer's to be selected from their various departments in the cities and towns of Oyo state.

\subsection{Research Design}

In other to achieve the research objectives, a survey approach-using questionnaire is used to elicit information from respondents who are the customers of Ade farm food production.

\subsection{Sources of Data}

Sources of data using in this research work was primary. Primary data referred to information that is first obtained by the researcher on the variables of interest for specific purpose of the study. For the purpose of this study, primary data will obtained through the distribution of questionnaire to all the customers of Ade farm from various cities in Oyo state.

\subsection{Data Collection}

Data was collected using a structured of questionnaire which consisted of items. The questionnaires were distributed to individual customers of Ade farm food production. These questionnaires were returned immediately to the researcher when it was completed.

\section{Results and Analysis The Company}

Farmers Food production is a Kisi-based company, located in Oyo state Nigeria, whose mission is to provide high quality, nutritional, and flavorful semovita and gari for consumption in both near and remote regions of the Nigeria. Additionally the company will provide high quality planting materials for use nationwide.

Farmers Food production is the one of successful food farms. The idea behind the business is to provide healthy and delicious semovita and mails to the public. In addition to semovita and mails the company plans to produce and market manure compost garden amendment products. 
Farmers Food Production management team is led by Mr. Kola J.A as Business Manager, who has extensive knowledge of the industry. The company expects to employ five temporary employees during the equipment re-location phase, four employees on a permanent basis, and three part-time employees.

Products

Farmers Food Production plans to concentrate on cassava product, maize product, yam product, vegetable, semovita and gari as its primary product. This includes growing amala, mails. The company's farm will have a capacity sufficient to produce in excess of 200,000 lbs. of food per year. The company plans to utilize traditional and more advanced plant technologies to produce new cultivars of gari and Amala with locally-adapted superior characteristics for the growing area. This strategy will allow Farmers Food production to produce crops yam during most of the year and will allow double cultivation of the places with almost no additional heating necessary in the normal time of the months.

While at Farmers Food Production Mr Ademola Ige, steadily used and experimented with compost and fertilized with manure of different kinds. The product like, (CASSAVA, MAIZE, YAM), all this product have to do with seed for plants. The most important things with manure usage is to eliminate the viable weed seed and raw one drawback by thoroughly composting the manure, to add enough cellulose on product to bring it to the proper ratio and to bring its water content to proper levels. A properly composted manure product has no seeds that will germinate and proliferate in it. Additionally, a properly composted manure product has something a chemically formulated synthetic fertilizer does not have: enzymes. Enzymes are critical for producing a truly nutria food and superior flavored product. Research has shown that the superior flavor of a semovita or food product is closely related to vitamin content and folic acid content in Flower or Flower food.

The state-of-the-art food equipment starting up in the new location utilizes revolutionary harvest designs that:

[1] Allow faster, longer growth Cut the harvest labor by over $80 \%$

[2] Cut the harvest time and by so doing: Decrease loss in weight gain, and Eliminate weight loss from shock.

Marketing plan

Over the past decade the market for organics food has grown by $15 \%$ to $20 \%$ and every year $40 \%$ of Nigeria consumers occasionally reach for something strong organic. Sales for organic foods are expected to top $\$ 11$ billion this year. Sales by farmers' markets have increased by $79 \%$ since 1994, to 3,137 markets in all 36 states, and the number of farmers who sell at them has more than tripled to 67,000. About three million Nigerians a week now get their fresh food directly from the farmers who grew it. This makes for an excellent environment for a industry participant such as Farmers Food production that is willing to compete in a niche market and be first to the market with new products.

\section{Product Description}

Food

Farmers Food Production first line of production will be the Flower food and mill food. During the raining time Farmers Food production will be growing carrots, red onions, and spinach.etc In the fall, production will center on pumpkins, winter squash, globe beets and winter Flowers. With the growth of the popular organic food niche, and the federal government's new organic labeling policy, Farmers Food production will focus its produce on the intermediate organic label. This means that approximately $70 \%$ of the food production process will be organic and all foods produced by Farmers Food production will be eligible for the "contains organic ingredients" label. The company's farm will have a capacity sufficient to produce in excess of $200,000 \mathrm{lbs}$. of food per year.

\section{Financial Considerations}

The company is seeking $\$ 830,000$ in both short-term and long-term loans to finance the purchase of Farmers new materials farm, upgrade the facilities, and cover start-up expenses and first year losses. It is estimated that the company will begin to make a profit in Year 2 of operations. The company does not expect to have any cash flow problems during the first four years of operations.

\section{Start-up Summary}

Projected revenues for Year 1 to Year 5 are $\$ 40,000, \$ 8,500, \$ 50,000, \$ 70,800$ and $\$ 82,500$ respectively. Additionally the company estimates that once fully operational, income per product, per annum would be as follows; food ( $\$ 50,000)$ manure $(\$ 20,000)$ and horticulture $(\$ 10,000)$. 
Requirements

Start-up Expenses

Legal

Facilities modification

300,000

Seed

Organic Herbicides/Pesticides

Consultants

Insurance

10,000

Research and development

Expensed equipment

250,000

Other

50,000

Total Start-up Expenses

Start-up Assets

Cash Required

Start-up Inventory

Other Current Assets

Long-term Assets

$1,145,400$

$1,830,000$

Total Assets

Total Requirements

\section{Yam Flower}

The company's more technical horticultural aspects include efforts to utilize traditional and more advanced plant technologies to produce new cultivars of Flower such as gari and Amala with locally-adapted superior characteristics for the growing area. Flavor, disease resistance, adaptability to Flower-house culture, fall and winter season production are factors being combined in Flowers cultivation to tap into the $\$ 2.99$ pint berry market of the fall and winter.

Farmers Food Production strategy is a combination of the two technologies during the cool winter months which will allow the utilization of normally wasted space in the Flower houses for the high price winter Flowers production. This will allow double cultivation of the Flower houses with almost no additional heating necessary in this climate.

\section{Technology}

The company is currently seeking contact with UNAB universities in order to learn about and acquire new hybrids of Flowers food that are hardier and grow faster in our local microclimates. These and other available species and systems will be constantly tracked.

In addition to the above, the company is seeking contacts at Universities in North and East that are involved in Flowers food, and will continue the quest for the best flavored, large, and firm fall and timely food. 
Currently, Farmers Food production is conducting research to test certain clay-sand-manure mixture levels to obtain better, cheaper bedding and agronomic soil mixtures that are more effective than the standard used in the industry in Kisi (Pine bark mulch-composted).

\section{Future Products}

In the meantime, the company would like to explore the possibilities of crayfish production. Farmers Food production believes this to be a high revenue venture with retail prices running in excess of $\$ 15.00$ per pound in most places. The company also believes that if crayfish production is successful then it could become the number one endeavor of Farmers Food Production.

Currently there is a defunct fish farming production facility with all the necessary capital equipment approximately two miles from the current farm. Purchase of this facility would allow Farmers Food production to begin production and to capitalize on this higher margin product. What makes these most attractive ventures have significant cost potential, allowing for a reduction in marginal costs for all products and creation of real economies of scale that would provide Farmers Food production with a competitive advantage.

\section{Market Analysis Summary}

At a time when eating has become a political statement, the government is paying up to $\$ 9$ billion a year to subsidize commodity crops in a glutted global market. Federal officials say that nearly $40 \%$ of all farm income now comes directly from government subsidies, and the farm bill signed by President Obasanjo will pay $\$ 90$ billion over 10 years, which includes $\$ 23$ billion in new spending. However, there are two market niches that are growing at an amazing rate, the organic market and the simple farmers' market.

The organic market provides less than $2 \%$ of the nation's food supply and takes up less than $1 \%$ of its cropland. But organic farms are Flower is hing as never before. Over the past decade the market for organic food has grown by 15 to $20 \%$ and every year $40 \%$ of Nigeria consumers occasionally reach for something labeled organic or nafdac. Sales for organic foods are expected to top $\$ 3$ billion this year. Conglomerates as big as Yanaty and Golden Penny Mills are now launching or buying organic lines and selling them in mainstream supermarkets.

With no subsidies and no middle men, farmers' markets have increased by $79 \%$ since 1994 , to 3,137 markets in all 36 states, and the number of farmers who sell at them has more than tripled to 67,000, the Agriculture Department has reported. About three million Nigerians a week now get their fresh food directly from the farmers who grew it. "Right now, Flower markets are growing faster than anything in agriculture," said Dr. Wale, a farm economist at the University of Agriculture Abeokuta.

These numbers, of course, represent a very thin slice of the big pie of national food. Farmers' markets reported about $\$ 1$ billion in sales last year, compared with more than $\$ 20$ billion in overall farm revenue. Barely $3 \%$ of the nation's two million farmers sell some of what they grow directly to consumers.

But in an era of big-box food stores, when 10 major grocery chains control the purchase of $50 \%$ of fresh food, the proliferation of open-air markets has come out of nowhere, giving more consumers an option and allowing many small farmers to stay in business.

With these trends in mind, Farmers food production will concentrate on:

[1] Wholesale live food markets nationwide that sell organic produce and manure.

[2] Fresh farmers' markets.

[3] Fall and winter Flowers market.

[4] Nursery outlets selling composted manure.

\section{Market Segmentation}

The target customers include oriental food markets demanding organic and semi-organic Flower food, food processors, and private individual buyers through direct selling and farmers markets. The company will continue to service the existing customers of the purchased food farms. In its Flowers production the company will target virtually all main food outlets. The company plans to use the Internet as one of its marketing channels in the future.

The company's target customers will be as follows:

\section{Food:}

[1] Oriental food markets demanding organic and semi-organic food.

[2] Food processors.

[3] All fast food.

[4] People approaching the farm.

[5] Roadside stands and farmers' markets.

\section{Product-Bagged Manure:}

[1] Nursery and Garden Centers.

[2] Private customers approaching facility.

[3] Bulk customers. 
The company will also take over customers from the previous owner of the food facility. Farmers Food production has an established list of present customers of Errol food farm, which is a major asset to the sales of the company.

\section{Industry Analysis}

Kisi is one of the premier farming areas of the western Nigeria. This creates an intensely competitive environment with a large number of industry participants. Since almost all of the produce is considered to be commodities, and large scale buyers are more consolidated than the farmers themselves, overall margins are small and rivalries for wholesaler contracts are strong.

Competitive threats come from three main segments:

[1] Imported food of lower quality.

[2] O.B.J farm food.

[3] Kisi food producers.

Direct competition in the individual buyers' market segment comes from three farms in the immediate area including the Ade farm, Oloyoyo farm, and the Songa food farm. Each of these competitors has produce stands as well as selling to local farmers' markets. However, with the exception of none of the others focus on a niche market and depend heavily on federal subsidies.

\section{Target Market Segment Strategy}

The Market Analysis Pie shown below reflects the total number of potential customers for Farmers Food. The number of Oriental markets and food processors represent national estimates of industry participants, whereas the number of individual buyers represents the estimated annual number of individuals that will be driving by the farm.

Market Analysis

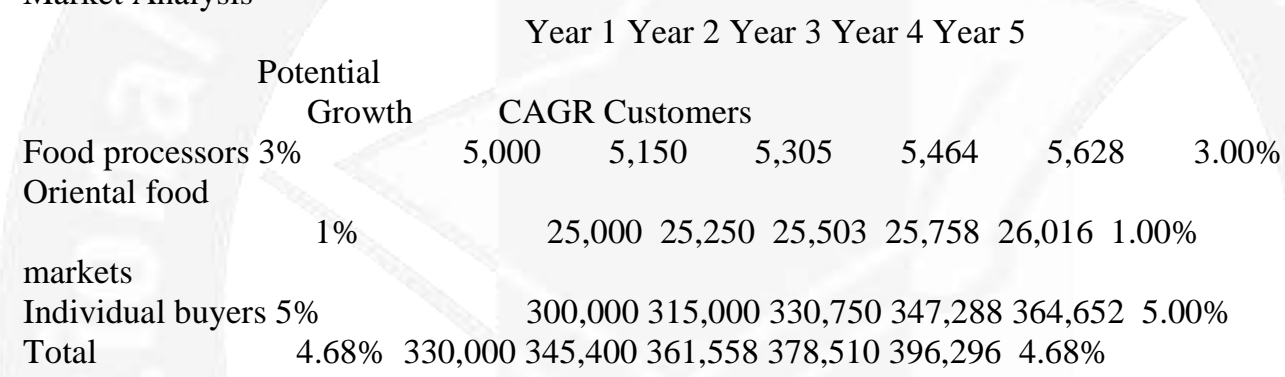

\section{Strategy and Implementation Summary}

The Farmers Food production strategy is to profitably and efficiently utilize present and future agricultural technology in the production of food. The company, by acquiring an existing profitable food farm with all the necessary custom-innovated equipment, will gain a significant industry advantage. Additional application and utilization of horticultural technology in the production of gari will allow double utilization of the climate controlled portion of the overhead. Farmers Food production hopes to consolidate considerable goodwill already created by exercising the option of not adding another high-production facility to the present supply demand scenario.

The company's goals in the first year are to:

[1] Prepare the future site.

[2] Relocate and expand Flower Acres food system and get it operational.

[3] Integrate Flowers culture into the system.

[4] Have the composting system in full production by early spring of the second year.

The company's long-term plan is to phase out whichever products are least lucrative and replace them with products that are practical and cost efficient.

\section{Competitive Edge}

Farmers Food's main competitive advantages are:

[1] Efficient production utilizing Flower houses.

[2] Reduced overhead by fully realizing crop output potential and economies of scale through cut costs.

[3] Knowledge due to research since 1990.

\section{Marketing Strategy}

Farmers Food production will initially market and supply its products to target customers. The company is further exploring marketing opportunities on the Internet. To this extent, the company would like to set up a website to market its products. The company will utilize aggressive advertising strategies to further market its products. These strategies include the promotion of products through the sponsoring of spots on cooking shows and exhibitions, and engaging prominent chefs to help promote this fledgling industry. 


\section{Pricing Strategy}

The company sets its pricing based on market rates as far as food products are concerned.

Farmers Food's pricing for gari will exceed the average market price for the following reasons:

[1] Taste sampling at outlets will be encouraged.

[2] Unparalleled flavour superiority will addict Flowers tasters.

[3] Promotion of pesticide-free, fumigant-free cultural techniques of soil, environment, ozone, and healthfriendly production techniques.

\section{Sales Strategy}

At Farmers Food, the sales process is primarily the same for food as it is for composting products, in that both products will be mainly sold through wholesale marketing. As in the past, live shipments will be delivered by contract carriers in special package barge carrying 8,000 tons of food or more, and will be continued as demanded. Farmers Food's bagged manure products will be delivered and unloaded in sizable wholesale quantities by the pallet. Smaller, more local orders will significantly increase the overall sales when the 300-450 live food carrying barge system is put into service late in 2000 or early in 2001.

The company's average sales cycle from first contact to closing of the sale is approximately 3 to 12 days for food products. Farmers Food production plans to shorten this cycle. Furthermore, the company estimates that from first contact to sale conclusion, the cycle for fresh gari will run 3 days or less. Composted products sale cycle should run from 3 to 12 days.

Direct sales contacts of food markets by delivery personnel, as well as cold calling by telephone of potential market outlets, will also be employed.

\section{Strategic Alliances}

The company has strategic alliances with:

[1] UNAB University Agriculture Department.

[2] College of Agriculture Oyo State Biology Department.

[3] Dr. Wale Omolara - Food Specialist.

[4] Joy Abby - Horticultural Inspection

[5] Charles Moffe - Wildlife and farmer.

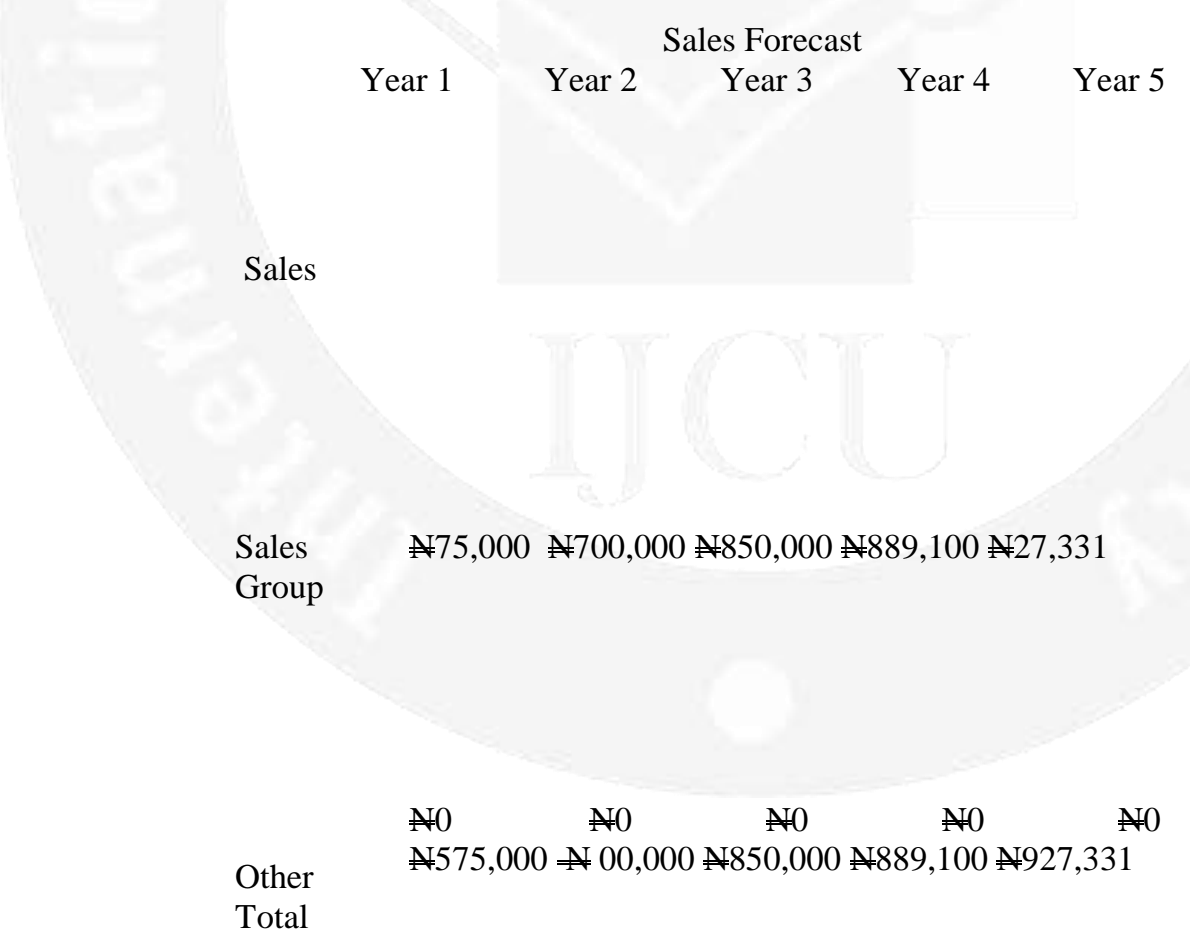

Sales

Direct

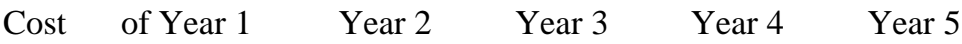

Sales

Sales

$\$ 391,000 \$ 78,100 \quad \$ 578,850 \$ 601,032 \$ 627,803$ 


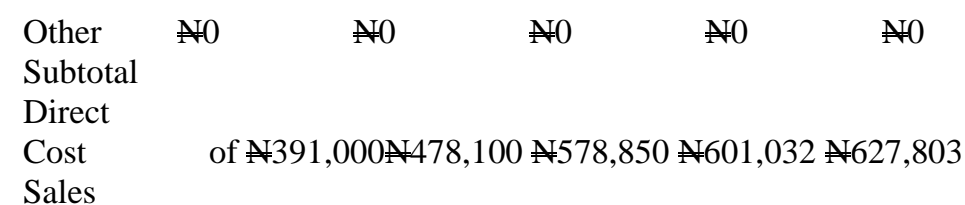

\section{Nature of Operations}

The company is in the business of food farming, Flowers cultivation, and composting. The company expects to be operating in 2009.

\section{Revenues}

The company's revenue is derived primarily from the sale of food, like, Semovita, Gari, Maize, yam Flower, vegetable etc. and bagged composted manure products.

\section{Nature and Limitation of Projections}

This financial projection is based on sales volume at the levels described in the sales forecast section and presents, to the best of management's knowledge, the company's expected assets, liabilities, capital, and revenues and expenses. The projections reflect management's judgment of the expected conditions and its expected course of action given the hypothetical assumptions.

\section{Management Summary}

Farmers Food's Production management team is led by Mrs. Ademola A.A, Business Manager, and the current manager of production Farmers Food Farm, who has extensive knowledge of the industry and has been tracking food trends for 30 years.

The company's management philosophy is based on responsibility and mutual respect. Farmers Food production has an environment and structure that encourages productivity and respect for customers and fellow employees.

\section{Personnel Plan}

Overall, Farmers Food production will have 12 personnel. The company expects to employ 5 temporary employees during the equipment re-location phase, 4 employees on a permanent basis, and 3 part-time employee. The Farmers Food production team is organized into three foods:

\section{Management}

Management will be responsible for supervising and participating in the daily operations of the facility. Management consists of:

[1] Mrs. Ademola A.A, Business Manager, Full Time

[2] Mr. Ademola A.A, Executive Director, Full Time

[3] Mr. Wole O, Management Trainee, 3/4 Time

[4] Mrs. Florence A, Management Trainee, 1/4 Time

\section{Daily Maintenance}

This food production will consist of the following:

[1] Micheel Joy, Logistical Engineer, Full Time

[2] NurudeenOlaoye, Heavy Equipment, Full Time

[3] K. B Bola, Welder, 1/2 Time

\section{Contract Personnel}

They will be utilized initially for the moving and setting up of the food farm, Flower houses, and the building of the manure composting facility.

Personnel Plan

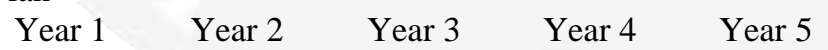

Business $\$ 25,000 \$ 30,000 \$ 30,000 \$ 30,000 \$ 30,000$

Manager

Executive $\$ 25,000 ¥ 30,000 \$ 30,000 \$ 30,000 \$ 30,000$

Director

Manager $\$ 9,000 \quad \$ 6,000 \quad \$ 6,000 \$ 6,000 \$ 6,000$

Trainee

Manager $\$ 4,000 \quad \$ 6,000 \quad \$ 6,000 \$ 6,000 \quad \$ 6,000$

Trainee

Logistic $\$ 18,000 \$ 18,000 \$ 18,000 \$ 18,000 \$ 18,000$

Engineer

Heavy $\$ 18,000 \$ 18,000 \$ 18,000 \$ 18,000 \$ 18,000$

Equipment

Welder $\$ 3,500 \quad \$ 3,000 \quad \$ 3,000 \quad \$ 3,000 \quad \$ 3,000$




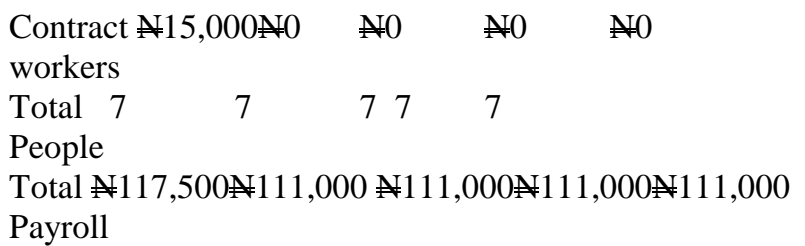

Financial plan summary funding requirements and uses

The company is seeking to raise of $\$ 830,000$ for the purpose of financing the Food Production Farm, facilities modifications, equipment, and funding operating expenses. Another $\$ 1,000,000$ will be invested in the company by its owners. The following is a breakdown of how the funds will be used:

\begin{tabular}{|c|c|}
\hline Breakdown of Use of Funds & \\
\hline Property & $¥ 1,300,000$ \\
\hline Equipment System & $¥ 400,000$ \\
\hline Sub-total & $¥ 1,700,000$ \\
\hline Operating Expenses: & \\
\hline Salaries & $\$ 80,000$ \\
\hline Marketing and promotion & $¥ 10,000$ \\
\hline Other operating expenses & $¥ 10,000$ \\
\hline Sub-total & $¥ 100,000$ \\
\hline Total & $\# \mathbf{1 , 8 0 0 , 0 0 0}$ \\
\hline
\end{tabular}

Start-up Funding

Start-up Expenses to Fund

$¥ 684,600$

Start-up Assets to Fund

$¥ 1,145,400$

Total Funding Required

Assets

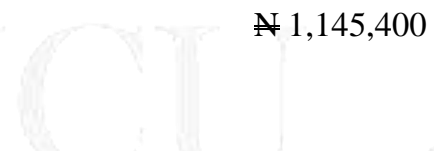

$¥ 1,830,000$

Non-cash Assets from Start-up

$\$ 900,000$

Cash Requirements from Start-up

$¥ 245,400$

Additional Cash Raised

Cash Balance on Starting Date

$\checkmark 245,400$

Total Assets

N $1,145,400$

$¥ 0$

Liabilities and Capital

Liabilities

Current Borrowing

Long-term Liabilities

Accounts Payable (Outstanding Bills) 30,000

Other Current Liabilities (interest-free) 0 
Total Liabilities

Capital

Planned Investment

Investor 1
Investor 2
Investor 3
Investor 4
Other

N830,000

\section{Important Assumptions}

\section{Nature and Limitation of Projections}

This financial projection is based on sales volume at the levels described in the sales forecast section and presents, to the best of management's knowledge, the company's expected assets, liabilities, capital, and revenues and expenses. The projections reflect management's judgment of the expected conditions and its expected course of action given the hypothetical assumptions.

\section{Nature of Operations}

The company is in the business of food farming, Flowers cultivation, and composting. The company expects to be operating in 2009.

\section{Revenues}

The company's revenue is derived primarily from the sale of food, like, semovita, gari,maize, yam Flower, vegetable etc. and bagged composted manure products.

\section{Expenses}

The company's expenses are primarily those of salaries, utilities, and insurance costs. Other expenses are based on management's estimates and industry averages.

\begin{tabular}{|c|c|c|c|c|c|}
\hline & & eral Assu & & & \\
\hline & Year 1 & Year 2 & Year 3 & Year 4 & Year 5 \\
\hline Plan Month & 1 & 2 & 3 & 4 & 5 \\
\hline Current Interest Rate & $7.00 \%$ & $7.00 \%$ & $7.00 \%$ & $7.00 \%$ & $7.00 \%$ \\
\hline Long-term Interest Ra & & $7.00 \%$ & $7.00 \%$ & $7.00 \%$ & $7.00 \%$ \\
\hline Tax Rate & $20.83 \%$ & $20.00 \%$ & $20.83 \%$ & $20.00 \%$ & $20.83 \%$ \\
\hline Other & 0 & 0 & 0 & 0 & 0 \\
\hline
\end{tabular}


Break-even Analysis

The company's break-even analysis is given below.

Break-even Analysis

Monthly Revenue Break-even $\$ 36,974$

Assumptions:

Average Percent Variable Cost $68 \%$

$\$ 11,832$

Estimated Monthly Fixed Cost

Projected Profit and Loss

As the profit and loss table shows, Farmers Food production expects a steady growth in profitability over the next few years.

Pro Forma Profit and Loss

\begin{tabular}{|c|c|c|c|c|c|}
\hline & Year 1 & Year 2 & Year 3 & Year 4 & Year 5 \\
\hline Sales & $\$ 575,000$ & $\$ 700,000$ & $\# 850,000$ & $\# 889,100$ & $\Downarrow 927,331$ \\
\hline Direct Cost of Sales & $¥ 391,000$ & $\Uparrow 478,100$ & $\$ 578,850$ & $¥ 601,032$ & $¥ 627,803$ \\
\hline Other & $\$ 10,000$ & $\$ 10,000$ & $\$ 10,000$ & $\$ 10,000$ & $\$ 10,000$ \\
\hline Total Cost of Sales & $\# 401,000$ & $¥ 488,100$ & $¥ 588,850$ & $¥ 611,032$ & $¥ 637,803$ \\
\hline Gross Margin & $\$ 174,000$ & $\Downarrow 211,900$ & $\Vdash 261,150$ & $\Vdash 278,068$ & $\Downarrow 289,528$ \\
\hline & $30.26 \%$ & $30.27 \%$ & $30.72 \%$ & $31.28 \%$ & $31.22 \%$ \\
\hline $\begin{array}{l}\text { Gross Margin \% } \\
\text { Expenses }\end{array}$ & & & & & \\
\hline Payroll & $\$ 117,500$ & $\$ 111,000$ & $¥ 111,000$ & $\$ 111,000$ & $¥ 111,000$ \\
\hline Sales and Marketing and & $\nexists 11400$ & $¥ 11100$ & $¥ 16,550$ & $\sharp 15,300$ & $\$ 17550$ \\
\hline Other Expenses & & & & & \\
\hline $\begin{array}{l}\text { Depreciation } \\
\text { Gas and Oil }\end{array}$ & $\begin{array}{l}\sharp 0 \\
\# 2,040\end{array}$ & $\begin{array}{l}\sharp 0 \\
\# 3,000\end{array}$ & $\begin{array}{l}\# 0 \\
¥ 3,000\end{array}$ & $\begin{array}{l}\sharp 0 \\
¥ 3,000\end{array}$ & $\begin{array}{l}\sharp 0 \\
\# 3,000\end{array}$ \\
\hline Utilities & $¥ 6,000$ & $¥ 6,000$ & $¥ 6,000$ & $\sharp 6,000$ & $¥ 6,000$ \\
\hline Insurance & $\$ 5,040$ & $\$ 5,500$ & $\$ 5,500$ & $\$ 5,500$ & $\$ 5,500$ \\
\hline Payroll Taxes & N0 & N0 & N0 & $\Uparrow 0$ & N0 \\
\hline Other & $\sharp 0$ & $¥ 0$ & N0 & N0 & N0 \\
\hline & & $\$ 136,600$ & $¥ 142,050$ & $\$ 140,800$ & $\$ 143,050$ \\
\hline
\end{tabular}

Total Operating Expenses Profit Before Interest and

EBITDA

Interest Expense
$\$ 141,980$

$\$ 32,020$ Taxes $\$ 75,300 \quad \$ 119,100 \quad \$ 137,268 \quad \$ 146,478$

$\begin{array}{lllll}\# 32,020 & \$ 75,300 & \$ 119,100 & \$ 137,268 & \$ 146,478 \\ \$ 54,664 & \$ 47,845 & \$ 39,095 & \$ 32,095 & \$ 26,495\end{array}$




$\begin{array}{llllll}\text { Taxes Incurred } & \$ 0 & \$ 5,491 & \$ 16,668 & \$ 21,035 & \$ 24,996 \\ \text { Net Profit } & (\$ 22,644) & \$ 21,964 & \$ 63,337 & \$ 84,139 & \$ 94,987 \\ & & 3.14 \% & 7.45 \% & 9.46 \% & 10.24 \%\end{array}$

Net Profit/Sales

Pro Forma Balance Sheet

$\begin{array}{lllll}\text { Year } 1 & \text { Year } 2 & \text { Year } 3 & \text { Year } 4 & \text { Year } 5\end{array}$

Assets

Current Assets $\#$

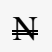

$\# \quad \#$

Cash

Accounts Receivable

Inventory

Other Current Assets $\begin{array}{lllll}545,740 & 454,763 \quad 482,017 & 482,346 & 484,581\end{array}$

Long-term Assets

\begin{tabular}{cccccc}
\multicolumn{1}{c}{239,980} & 180,177 & 202,250 & 201,210 & 182,106 \\
0 & 0 & 0 & 0 & 0 \\
55,760 & 24,586 & 29,767 & 31,136 & 32,475 \\
250,000 & 250,000 & 250,000 & 250,000 & 270,000 & Total Current Assets
\end{tabular}

Long-term Assets

$500,000500,000500,000500,000500,000$

Accumulated Depreciation $\$ 0$

Total Long-term Assets

$\$ 0$

Total Assets

$\begin{array}{cc}500,000 & 500,000 \\ 1,045,740 & 954,763\end{array}$

$¥ 0$

Liabilities and Capital

Year 1

Year 2

500,000

982,017

\# 0

$¥ 0$

Current Liabilities

Year 3

500,000

500,000

$982,346 \quad 984,581$

Year 4 Year 5

Accounts Payable

Current Borrowing

$\begin{array}{lllll}6,984 & 44,043 & 55,960 & 57,150 & 59,399 \\ 346,000 & 246,000 & 146,000 & 121,000 & 86,000 \\ 0 & 0 & 0 & 0 & 0\end{array}$

Other Current Liabilities

0

$0 \quad 0$

0

Subtotal Current Liabilities \$352,984 $\$ 290,043 \approx 201,960 \approx 178,150 \$ 145,399$

$\begin{array}{lllll}\text { Long-term Liabilities } & \$ 400,000 & 375,000 & 350,000 & 300,000\end{array}$

Total Liabilities

Paid-in Capital

Retained Earnings

$752,984 \quad 665,043 \quad 551,960 \quad 478,150$

250,000

Earnings

$1,000,000 \quad 1,000,000 \quad 1,097,000 \quad 1,097,000 \quad 1,097,000$

Total Capital

$(22,644) \quad 21,964$

21,964
289,720

$(730,280)$

$(676,943)(602,804)$

Total Liabilities and Capital 1,045,740 954,763

Net Worth

292,756

289,720

430,057

84,139

94,987

$982,017 \quad 982,346 \quad 984,581$ 


\section{Business Ratios}

The business ratios given below are contrasted to industry standards for SIC code 0161 which covers food and melon growers. Within this category, research has shown that there can be significant deviations from industry standards due to farm size, product life cycle, and capital resources.

Farmers Food production is a start-up venture, and therefore has a more heavy debt to equity ratio than most existing farms. Furthermore, due to its move into a niche market, the company is expected to spend more on advertising than its competitors. The first two years of operations are expected also to have a higher growth rate than average as it gains market share.

Ratio Analysis

Sales Growth

Year 1

Year

Year $3 \quad$ Year 4

Year 5

Percent of Total Assets

$0.00 \%$

$21.74 \% \quad 21.43 \% \quad 4.60 \%$

$4.30 \%$

Accounts Receivable

Inventory

Other Current Assets

Total Current Assets

Long-term Assets

Total Assets

Current Liabilities

Long-term Liabilities

Total Liabilities

Net Worth

Percent of Sales

Sales

Gross Margin

$\begin{array}{lllll}0.00 \% & 0.00 \% & 0.00 \% & 0.00 \% & 0.00 \% \\ 5.33 \% & 2.58 \% & 3.03 \% & 3.17 \% & 3.30 \%\end{array}$

$23.91 \% \quad 26.18 \% \quad 25.46 \% \quad 25.45 \% \quad 27.42 \%$

$52.19 \% \quad 47.63 \% \quad 49.08 \% \quad 49.10 \% \quad 49.22 \%$

$\begin{array}{lllll}47.81 \% & 52.37 \% & 50.92 \% & 50.90 \% & 50.78 \%\end{array}$

$\begin{array}{lllll}100.00 \% & 100.00 \% & 100.00 \% & 100.00 \% & 100.00 \%\end{array}$

$33.75 \% \quad 30.38 \% \quad 20.57 \% \quad 18.14 \% \quad 14.77 \%$

$38.25 \% \quad 39.28 \% \quad 35.64 \% \quad 30.54 \% \quad 25.39 \%$

$\begin{array}{lllll}72.00 \% & 69.66 \% & 56.21 \% & 48.67 \% & 40.16 \%\end{array}$

$28.00 \% \quad 30.34 \% \quad 43.79 \% \quad 51.33 \% \quad 59.84 \%$

$100.00 \% \quad 100.00 \% \quad 100.00 \% \quad 100.00 \% \quad 100.00 \%$

$30.26 \% \quad 30.27 \% \quad 30.72 \% \quad 31.28 \% \quad 31.22 \%$

Selling, General \& Administrative

$37.26 \% \quad 29.04 \% \quad 24.76 \% \quad 23.31 \% \quad 22.31 \%$

Expenses

Advertising Expenses

Profit Before Interest and Taxes

Main Ratios

$\begin{array}{lllll}0.83 \% & 0.71 \% & 1.23 \% & 1.20 \% & 1.23 \%\end{array}$

$\begin{array}{llllll}5.57 \% & 10.76 \% & 14.01 \% & 15.44 \% & 15.80 \%\end{array}$

Current

1.55

1.57

2.39

2.71

3.33

Quick

1.39

1.48

2.24

2.53

3.11

Total Debt to Total Assets

$72.00 \% \quad 69.66 \% \quad 56.21 \% \quad 48.67 \% \quad 40.16 \%$ 


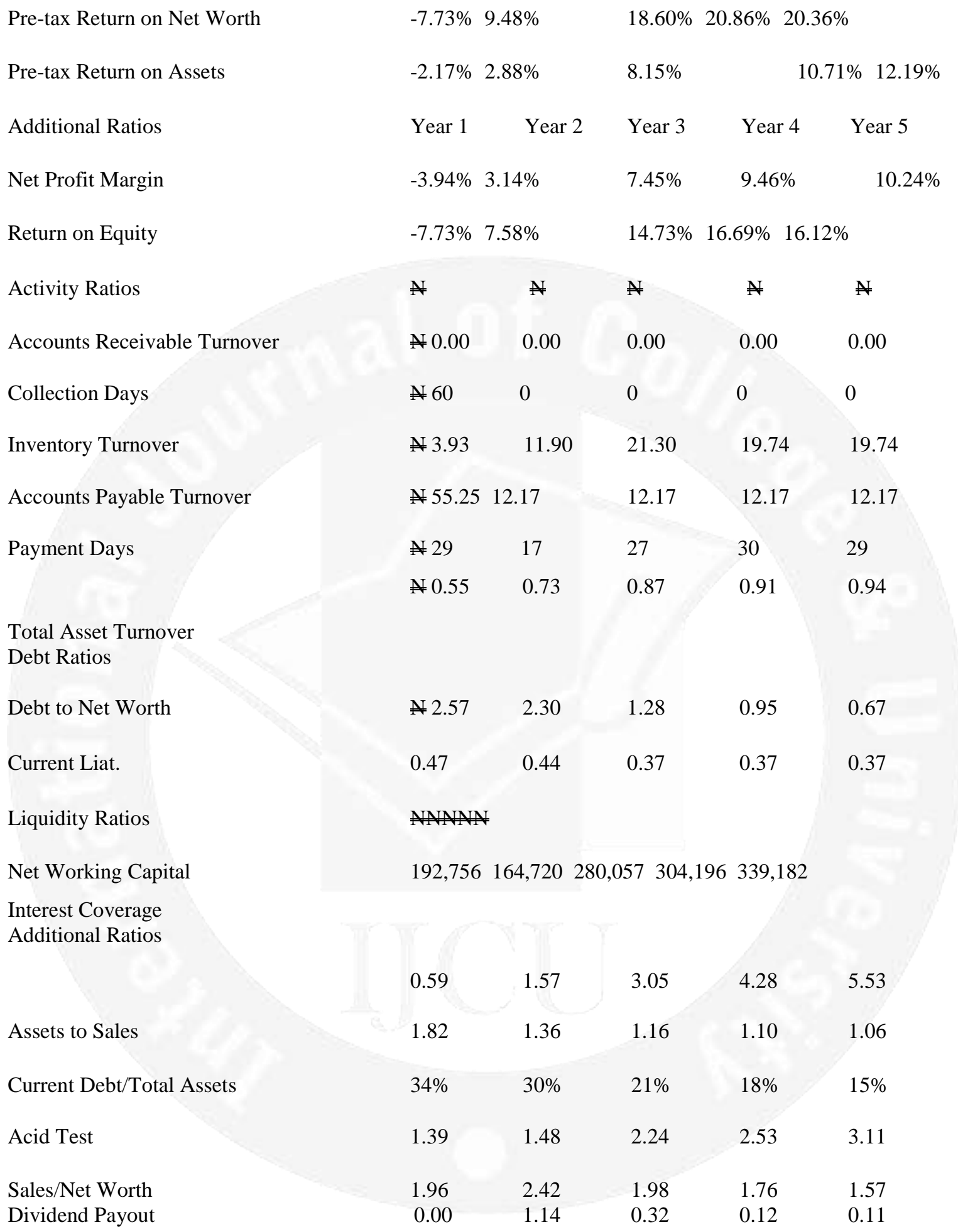

\section{Conclusion}

Provide a statement that what is expected, as stated in the "Introduction" chapter can ultimately result in "Results and Discussion" chapter, so there is compatibility. Moreover, it can also be added the prospect of the development of research results and application prospects of further studies into the next (based on result and discussion). 


\section{Acknowledgement}

We give our first and foremost appreciation to AMIGHTY GOD, the creator of heaven and earth and all that dwell in it, the lifter of our head, the commander of the universe, our strength, shield, fortress and hope. He has been gracious and compassionate in protecting us throughout our studies. Thank you so much my LORD. Thanks again my LORD, the completion of this project would not have been possible without the grace of Almighty Allah both spiritual and physical kind of support and valuable assistance of several people whom we would like to acknowledge. We will forever be grateful to Dr. Arafan Shahzad, for painstakingly checking our scripts and for him constructive directing us, which has helped us a long way in the successful completion of this article. Special thanks to him again Dr. Arafan S, man of courage, thanks for his continuing support and encouragement during the course of our studies and writing of this thesis. Thank you, for all that you did, also, thanks respondents and those that give us materials for successful completion of this article.

\section{References}

[1] Abalu, et al. (n.d.) The Green Revolution in Nigeria? Samaru, Institute for Agricultural Research, Ahmadu Bello University.

[2] Adegboye, R.O. 1966. Farm tenancy in western Nigeria. The Nigerian Journal of Economic and Social Studies, vol.8, 3 .

[3] Afolayan, A.A. (n.d.) Rural Migration and Socio-economic Conditions of the Source Region: Ebira Division, Nigeria.

[4] Agboola, A.A. 1979. An Agricultural Atlas of Nigeria. Oxford Univ. Press, Oxford:.Ajiki, K. \& S. Shimada 1990. 70-nendai-ikou-no-naijeria-nouson-ni-okeru- nougyou-keieino-henka (in English: A study on changes in the farming system in Nigeria since the 1970s). Afurika-kenkyu (Journal of African Studies), vol. 37.

[5] Agricultural Economic, 41: 51-66.

[6] Akpan, E. (2009). Oil Resource Management and Food Insecurity in Nigeria. Paper Presented at the European Report on Development (ERD) Conference in Accra, Ghana, 21-23 May, 2009.

[7] Aluko, S.A. 1973. Industry in the rural setting. Rural Development in Nigeria: Proceedings of the 1972 Annual Conference of the Nigerian Economic Society . Berry, S.S. 1975. Cocoa, Custom and Socioeconomic Change in Rural Western Nigeria. Clarendon Press, Oxford.

[8] Anriquez, G. and Daidone, S. (2010). Linkages between the Farm and Nonfarm Sectors at the Household Level in Rural Ghana: A Consistent Stochastic Distance Function Approach.

[9] Babatunde, R.O. and Qaim, M. (2009). Patterns of Income Diversification in Rural Nigeria: Determinants and Impacts. Quarterly Journal of International Agriculture, 48(4): 305-320.

[10] Barrett, C.B., Reardon, T. and Webb, P. (2001). Nonfarm Income Diversification and Household Livelihood Strategies in Rural Africa: Concepts, Dynamics, and Policy Implications. Food Policy, 26(4), 315-331.

[11] Block, S. and Webb, P. (2001). The Dynamics of Livelihood Diversification in PostFamine Ethiopia. Food Policy, 26(4), 333-350.

[12] Bonat, Z.A. 1989. Agriculture. In (Kayade, M. O. and Usman, Y. B. eds.) Nigeria since Independence: The First Twenty-five Years: vol. II; (The Economy). Heinemann Educational Books, Ibadan, Nigeria.

[13] Central Bank of Nigeria 1992a. Impact of Structural Adjustment Programme (SAP) on Nigerian Agriculture and Rural Life, vol. I: The National Report, CBN/NISER, Lagos. Essang, S.M. 1973.

[14] Chang, H.H. and Wen, F.I. (2011). Off-farm Work, Technical Efficiency and Production Risk: Empirical Evidence from a Rice Farmer Survey in Taiwan. Agricultural Economics, 42(2011): 269-278.

[15] Chavas, J., Petrie, R. and Roth, M. (2005). Farm Households Production Efficiency: Evidence from the Gambia. American Journal of Agricultural Economics, 87(1): 160-179.

[16] Coelli, T., Prasada Rao, D.S., O'enonnell, C.J. and Battese, G.E. (1998). An Introduction to Efficiency and Productivity Analysis. Kluwer Publishers, Boston.

[17] Collier, P. and Lal, D. (1986). Labour and Poverty in Kenya 1900-1980. Oxford University Press, New York. 
[18] Davis, B., Winters, P., Carletto, G., Covarrubias, K., Quinones, E., Zezza, A., Stamoulis, K., Bonomi, G. and Digiuseppe, S. (2007). Rural income Generating Activities: A Cross Country comparison. ESA Working Paper No. 07-16, Agricultural Development Economics Division, FAO, Rome, Italy.

[19] De Janvry, A. and Sadoulet, E. (2001). Income Strategies among Rural Households in Mexico: the Role of Off-farm Income. World Development, 29(3), 467-480.

[20] De Janvry, A. Sadoulet, E. and Zhu, N. (2005). The Role of Non-farm Incomes in Reducing Rural Poverty and Inequality in China. CUDARE Working Paper No. 1001, Department of Agricultural and Resources Economics, University of California, Berkeley.

[21] Deaton, A. (1997). The Analysis of Household Surveys. Johns Hopkins University Press, Baltimore, MD.

[22] Deininger, K., Savastano, S. and Carletto, C. (2007). Land Market Development and Agriculture

[23] Economics and Transition: What Was Expected, What We Observed, the Lessons Learned." Corvinus University, Budapest, Hungary.

[24] Efficiency in Albania. Paper Presented at the 104th EAAE/IAAE Seminar "Agricultural

[25] The „Land Surplus ${ }^{\text {ee }}$ Notion and Nigerian agricultural development policy. West African Journal of Agricultural Economics (WAJAE), 2 (1). 


\section{Biography of Authors}

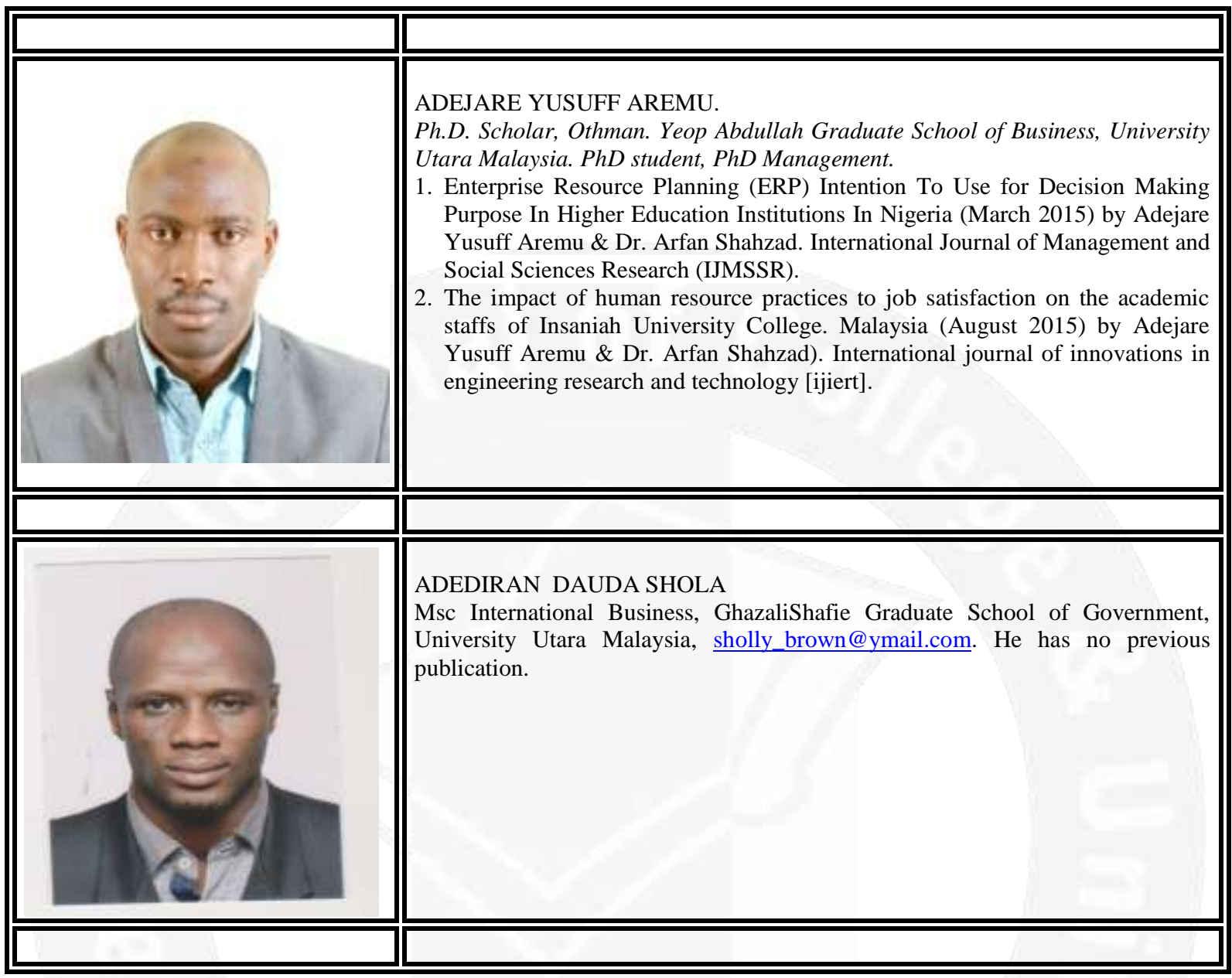

